\title{
Bilateral Marcus Gunn jaw-winking syndrome
}

A 10-year-old boy presented with alternating elevation of his eyelids upon chewing, present since birth (video on the Neurology ${ }^{\circledR}$ Web site at Neurology.org). Examination showed mild left ptosis but no ophthalmoparesis. This represents Marcus Gunn jaw-winking syndrome (MGJWS), also called trigemino-oculomotor synkinesis or pterygoid-levator synkinesis. It likely results from aberrant connections in the midbrain between trigeminal mesencephalic nucleus and oculomotor nucleus, although others have postulated connections between the mandibular division of trigeminal nerve innervating lateral pterygoid and the superior division of oculomotor nerve innervating levator palpebrae superioris. MGJWS occurs in $2 \%-13 \%$ of patients with congenital ptosis. ${ }^{1}$ It is usually unilateral but rarely presents bilaterally. ${ }^{2}$

Deepa Kannaditharayil, MD, Howard Geyer, MD, PhD, Henry Hasson, MD, Steven Herskovitz, MD From Montefiore Medical Center (D.K., H.G., S.H.), Bronx; and private practice (H.H.), Brooklyn, NY.

Author contributions: Deepa Kannaditharayil: drafting/revising the manuscript, accepts responsibility for conduct of research and final approval. Howard Geyer: drafting/revising the manuscript, study concept or design, analysis or interpretation of data, accepts responsibility for conduct of research and final approval. Henry Hasson: drafting/revising the manuscript, analysis or interpretation of data, accepts responsibility for conduct of research and final approval, acquisition of data. Steven Herskovitz: drafting/revising the manuscript, study concept or design, analysis or interpretation of data, accepts responsibility for conduct of research and final approval. Study funding: No targeted funding reported.

Disclosure: The authors report no disclosures relevant to the manuscript. Go to Neurology.org for full disclosures.

Correspondence to Dr. Kannaditharayil: deepa.kannaditharayil@hotmail.com

Supplemental data at Neurology.org
1. Demirci H, Frueh BR, Nelson CC. Marcus Gunn jaw-winking synkinesis: clinical features and management. Ophthalmology 2010;117:1447-1452.

2. Shah AD, Kumar AB, Kothari K. Bilateral Marcus Gunn jaw winking synkinesis with monocular elevation deficiency: a case report and literature review. Int Ophthalmol 2012;32:199-201. 


\title{
Neurology
}

\author{
Bilateral Marcus Gunn jaw-winking syndrome \\ Deepa Kannaditharayil, Howard Geyer, Henry Hasson, et al. \\ Neurology 2015;84;1061 \\ DOI 10.1212/WNL.0000000000001338
}

This information is current as of March 9, 2015

$\begin{array}{ll}\begin{array}{l}\text { Updated Information \& } \\ \text { Services }\end{array} & \begin{array}{l}\text { including high resolution figures, can be found at: } \\ \text { http://n.neurology.org/content/84/10/1061.full }\end{array} \\ \text { Supplementary Material } & \begin{array}{l}\text { Supplementary material can be found at: } \\ \text { http://n.neurology.org/content/supp1/2015/03/07/WNL.0000000000001 } \\ \text { 338.DC1 }\end{array} \\ \text { This article cites } 2 \text { articles, } 0 \text { of which you can access for free at: } \\ \text { http://n.neurology.org/content/84/10/1061.full\#ref-list-1 }\end{array}$

Neurology ${ }^{\circledR}$ is the official journal of the American Academy of Neurology. Published continuously since 1951, it is now a weekly with 48 issues per year. Copyright (C 2015 American Academy of Neurology. All rights reserved. Print ISSN: 0028-3878. Online ISSN: 1526-632X.

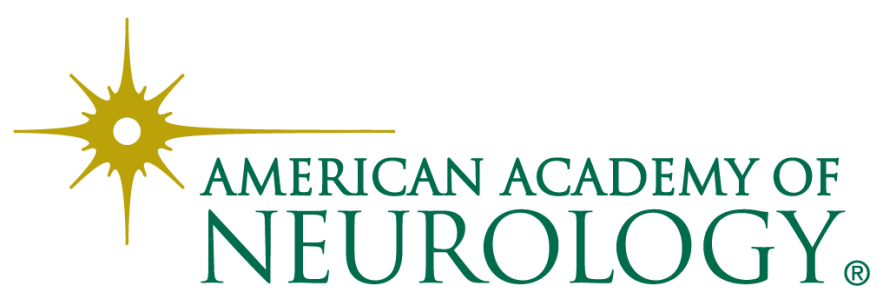

